\title{
Transformação agrária e desapropriação de terras indígenas em Mato Grosso (1940-1960): O caso da reserva Kadiwéu
}

Agrarian transformation and expropriation of indigenous lands in Mato Grosso, 1940-1960: the case of the Kadiwéu reserve

José Manuel Flores

\section{(2) OpenEdition Journals}

\section{Edição electrónica}

URL: http://journals.openedition.org/aa/3011

DOI: 10.4000/aa.3011

ISSN: 2357-738X

\section{Editora}

Programa de Pós-Graduação em Antropologia Social (UnB)

\section{Edição impressa}

Data de publição: 1 julho 2018

Paginação: 285-314

ISSN: 0102-4302

\section{Refêrencia eletrónica}

José Manuel Flores, «Transformação agrária e desapropriação de terras indígenas em Mato Grosso (1940-1960): O caso da reserva Kadiwéu», Anuário Antropológico [Online], v.43 n.1 | 2018, posto online no dia 26 maio 2019, consultado o 27 abril 2021. URL: http://journals.openedition.org/aa/3011 ; DOl: https://doi.org/10.4000/aa.3011

\section{@) $\Theta \Theta \Theta$}

Anuário Antropológico is licensed under a Creative Commons Atribuição-Uso Não-Comercial-Proibição de realização de Obras Derivadas 4.0 International. 


\section{Transformação agrária e desapropriação de terras indígenas em Mato Grosso (1940-1960): O caso da reserva Kadiwéu}

José Manuel Flores

UFRR

\section{Introdução}

O processo de perda territorial dos povos indígenas que habitam o estado de Mato Grosso do Sul, bem como das disputas legais e confrontos violentos pela reivindicação dos territórios, em particular a partir de 1988, tem sido alvo de um considerável e ainda crescente número de pesquisas e trabalhos acadêmicos. Isto é particularmente visível para o caso dos grupos Guarani (Pereira, 2002, 2005, 2007; Mura, 2004, 2006: Lutti, 2009; Silva, 2007; Crespe, 2015; Pacheco, 2009; Pacheco, 2004; Cavalcante, 2013) e, em menor medida, dos Terena (Azanha, 2005; Eremites de Oliveira e Pereira, 2003, 2007, 2017). No caso dos Kadiwéu, no entanto, a afirmação anterior constitui ainda uma expectativa. Apesar das múltiplas referências a esse processo, espalhadas em inúmeros trabalhos, apenas alguns poucos trabalhos analisam especificamente o processo de ocupação por fazendeiros pecuaristas das terras Kadiwéu, tal como foram demarcadas no início do século XX (cf. Silva, 2004; Muller, 2011).

O objetivo deste artigo é limitado, porém não irrelevante: pretende responder à pergunta de como foi possível a ocupação massiva, por estranhos, das terras Kadiwéu, inserindo a discussão no contexto da profunda transformação da estrutura agrária no sul do Mato Grosso nas décadas de 1940 e 1950. A ocupação do espaço que hoje é o Mato Grosso do Sul não foi espontânea: tanto os novos colonos como os empreendedores que chegaram à região para estabelecer fazendas, assim como especuladores ávidos de lucro, o fizeram com a perspectiva de aproveitar as oportunidades apresentadas pelo avanço da fronteira agrícola ${ }^{1}$. Um projeto em grande parte dirigido, não menos consciente quanto o "vazio" anterior - na medida em que se desencorajou um movimento colonizador - e funcional à grande propriedade agrária, que sustentou em Mato Grosso as oligarquias políticas da República Velha e o sistema produtivo predominante.

A partir da quarta década do século XX, em uma tentativa de integrar pro- 
gressivamente os espaços do interior aos circuitos da economia nacional, o papel do Estado foi fundamental para configuração da fronteira e a desapropriação de terras indígenas, possibilitando o estabelecimento de novas relações de produção e o início de um novo ciclo de acumulação capitalista nacional. O intenso processo de ocupação da fronteira - baseado na aquisição de terras públicas e projetos de colonização - exerceu pressões cada vez maiores sobre as terras indígenas, que se tornaram alvo do interesse particular, vinculado à produção pecuária. Entre 1957 e 1960 quase a metade da área pertencente aos Kadiwéu, sobretudo as ricas em pastagens, foi, de fato, incorporada às propriedades colidentes através de formas de tratos produtivos e de invasão.

Um agente central, tanto na defesa como no processo de incorporação das terras Kadiwéu às dinâmicas produtivas no âmbito do capitalismo agrário emergente na fronteira, foi o Serviço de Proteção aos Índios (SPI) que, entre 1910 e 1967, foi o órgão do Estado encarregado da aplicação da política indigenista, baseada em noções particulares sobre a evolução, integração e tutela (cf. Lima, 1995). Em meados do século XX, no sul de Mato Grosso, o SPI, através da 5a Inspetoria Regional (IR5), sediada em Campo Grande, mantinha jurisdição sobre 11 Postos Indígenas (PI), que eram o espaço concreto da aplicação da política protecionista; e contavam com uma infraestrutura administrativa, escolar e produtiva, com frequência muito precária, sob a condução direta de um encarregado do Posto subordinado à chefia regional. Na reserva Kadiwéu, com mais de 350 mil hectares demarcados entre 1900 e 1903, instalaram-se três PI: Presidente Alves de Barros, São João e Nalique, dedicados, na sua função produtiva, à criação de gado bovino. Em 1960, em um contexto de invasões crescentes, a IR5 estabeleceu contratos produtivos com os próprios pecuaristas ocupantes ilegais das terras Kadiwéu, na forma de arrendamentos de áreas para pastagem, formalizando uma situação irregular criada nos anos precedentes. O artigo trata de pôr ênfase no papel do SPI na construção da dramática situação que levaria à desapropriação, de fato, de uma grande área da reserva Kadiwéu.

O texto divide-se em cinco seções que descrevem o referido processo de forma cronológica. A primeira aborda, introdutoriamente, as circunstâncias que influíram no estabelecimento da reserva Kadiwéu durante a Primeira República, assim como alguns dos conflitos fundiários nas primeiras décadas do século XX, durante o período de afastamento do SPI da região entre 1930 e 1941 . Na segunda seção, descreve-se o início da transformação da estrutura agrária no 
sul do MT, na década de 1940, expressada no ataque do Estado às grandes propriedades latifundiárias, como à Fomento Argentino Sul-americano S. A., bem como as implicações que teve sua desestruturação para a integridade da reserva. $\mathrm{Na}$ seguinte seção, expõe-se o período mais dinâmico da ocupação territorial do sul de Mato Grosso na década de 1950: a requisição e aquisição de terras devolutas, a compra de terras pertencentes às antigas propriedades ou cessão de terras a terceiros, que propiciaram, em poucos anos, a multiplicação de fazendas pecuaristas em volta dos limites da reserva Kadiwéu, desencadeando ondas de invasões e confrontos pelas divisas das propriedades. A ocupação massiva da reserva, na conjuntura propiciada pela acometida da Assembleia do Estado às terras indígenas em 1957, que tentou reduzir sua superfície para menos de um terço da área original, e o papel do SPI perante essas circunstâncias é o assunto tratado na quarta seção. Finalmente, se reflete, a partir de noções acerca da antropologia da formação do Estado, sobre o papel contraditório assumido pelo SPI na defesa da reserva e também como peça importante para a integração das terras indígenas aos circuitos da economia nacional ${ }^{2}$.

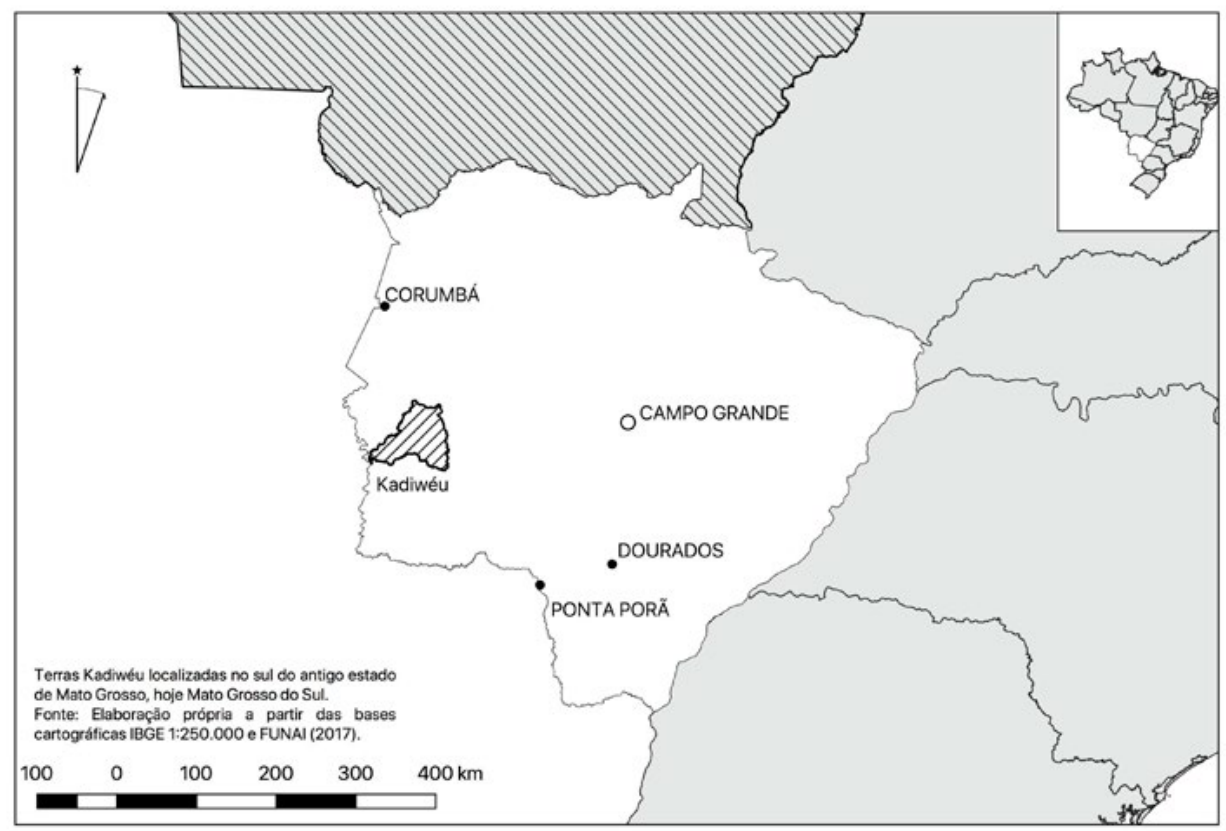




\section{A formação da reserva Kadiwéu e o reestabelecimento do SPI} (1864-1940)

Após a Guerra do Paraguai (1864-1870) - na qual combateram ao lado do exército imperial - e durante uma parte da Primeira República (1889-1930), seus territórios foram constantemente assediados e os Kadiwéu duramente combatidos. Destacou-se, entre seus opressores, Antônio Joaquim Malheiros, um obscuro coronel da Guarda Nacional durante o império, poderoso latifundiário, chamado de "atropelador de índios", e proprietário da fazenda Barranco Branco, entre outras, adjacente às terras Kadiwéu. Suas ligações políticas e os inúmeros cargos que ocupou lhe permitiram constituir-se em uma figura de influência política em Corumbá e construir um domínio sobre uma extensão considerável de terra ${ }^{3}$. Já em 1885, sendo Diretor dos Índios Cadiuéos (cargo que deixou em 1889), fora denunciado por utilizar o trabalho indígena em suas próprias fazendas e em serviços pessoais, sob coação e violência física ${ }^{4}$. Os confrontos entre os Kadiwéu e Malheiros foram costumeiros ao longo da República Velha e, em 1897 e 1898, foi necessário o envio de forças federais para reprimir as incursões índias nas fazendas de Malheiros. No entanto, as contendas ainda continuaram nos primeiros anos do século $\mathrm{XX}^{5}$.

É admirável que os Kadiwéu pudessem conservar e reivindicar um espaço de proporções consideráveis em um contexto de mudanças significativas, das quais Malheiros foi apenas uma expressão. De um lado, a formação da Primeira República esteve marcada pelo reordenamento não apenas do poder político, mas também da estrutura da propriedade rural, processos, aliás, que em uma sociedade agrária de fronteira - na qual o território era concebido como um imenso espaço ainda a ser explorado e civilizado - estavam intrinsicamente ligados. Da mesma forma em que as novas instituições democráticas funcionaram para consolidar a autoridade política de grupos oligárquicos que lutavam incessantemente entre si pelo poder político, a legislação republicana sobre terras permitiu a continuidade de velhos latifúndios e a formação conflituosa de novos, base e expressão daquele poder (Moreno, 1999, 2007; Trinidade, 1995). De outro, no decurso do final do século XIX e início do XX, e respondendo à reconfiguração do mercado mundial, a produção pecuária, junto à indústria extrativa, foi ocupando um lugar proeminente na economia do estado (cf. Wilkox, 2017; Corrêa e Corrêa, 2010; Trubiliano, 2014; Borges, 2001). Ano após ano, milhares de cabeças de gado bovino eram enviadas rumo aos matadouros paulistas, 
multiplicando, no próprio estado, a concorrência por campos de pastoreio.

É na conjunção desses processos - a confrontação entre elites políticas e econômicas, o reacomodo da estrutura agrária e a expansão da pecuária - que os Kadiwéu consolidaram seu domínio sobre as terras que lhes foram demarcadas. Diversos fatores contribuíram, em maior ou menor medida, para isso. A maneira como os Kadiwéu se inseriram nas lutas políticas ao longo da República Velha permitiu-lhes estabelecer as alianças necessárias para tal propósito. $\mathrm{Na}$ base do sistema oligárquico, estava um rígido sistema de vínculos pessoais, compromissos recíprocos, apoios mútuos, em um encadeamento que unia os níveis locais com os poderes estaduais e federais, e que estruturava a disputa pelo poder político e controle dos recursos. Esta dinâmica teve sua manifestação mais explícita nas múltiplas confrontações armadas ao logo do período (1892, 1899, 1901, 1906, 1916), nas quais os coronéis do sul incentivaram o separatismo da porção norte do estado como uma forma de participar do jogo político (cf. Arruda, 2015; Gilmara, 2014; Fanaia, 2010).

Os Kadiwéu participaram dessa dinâmica com sucesso. A demarcação da reserva, em 1900, e seu reconhecimento, em 1903, não podem ser entendidos senão no contexto da sua aliança com o governo estadual do coronel Pedro Alves de Barros (1899-1903), que ascendera ao poder após um cerco armado à Assembleia do Estado e à renúncia do presidente do estado anterior. Os Kadiwéu integraram os contingentes organizados para reprimir os movimentos armados de 1901 contra seu governo, promovidos pelos dois primeiros vice-presidentes do Estado $^{6}$. As disputas dos Kadiwéu com o coronel Malheiros, da mesma forma, se localizaram nos interstícios das disputas pelo poder político entre os coronéis regionais e o governo. Malheiros foi inimigo político de Barros, assim, para este último, apoiar as reivindicações indígenas tornou-se uma forma de conter pretensões daquele e, ainda, reprimi-las. As confrontações entre os Kadiwéu e Malheiros se tornaram ainda mais frequentes quando este deixou a administração de uma das suas fazendas mais importantes, Rio Branco, em mãos do coronel Bento Xavier, um dos chefes políticos com maior influência no sul do estado e que, um ano antes, havia levantado em armas ${ }^{7}$.

Os Kadiwéu se tornaram, dessa forma e em alguma medida, importantes para conter os movimentos armados e barrar as pretensões dos coronéis pelo poder político no âmbito local. A demarcação da reserva foi o reconhecimento imediato desse fato. A afirmação contrária também é correta: os índios utiliza- 
ram habilmente suas relações para armar-se, defender-se e conter os constantes embates em torno das suas terras, o que obrigou as autoridades políticas a estabelecer constantemente negociações com os índios. Outros fatores tiveram a mesma importância. A formação de grandes latifúndios em volta das suas terras contribuiu, de certa forma, para criar uma zona amortecedora que barrou a presença de outros fazendeiros, pequenos agricultores e posseiros, embora seja verdade que não houve um populacional como aquele que caracterizou o extremo sul, principalmente de imigrantes gaúchos provenientes do sul do país, e que provocara inúmeros conflitos entre posseiros e a Mate Laranjeira já em começos do século XX (Martins, 1999).

Da mesma forma, a localização do seu território foi, como explicado pelos próprios Kadiwéu ao etnólogo Kalervo Oberg (1949:56), um lugar estratégico, não apenas por representar uma zona rica para a caça, mas também desde o ponto de vista da sua defesa: cercadas à leste pela Serra da Bodoquena e por terras inundáveis ao sul e ao norte, às margens dos rios Aquidauana e Nabileque, era um lugar adequado contra as incursões de fazendeiros e índios inimigos. A própria morte de Malheiros, em 1908, contribuiu para garantir definitivamente o controle desse território. Finalmente, a presença do SPI na década de 1910 e a construção de caminhos, pontes, instalações e a chegada de funcionários, permitiram que, mesmo com a retirada posterior do órgão indigenista por mais de dez anos, não houvesse durante esse tempo nenhum inimigo que representasse um sério perigo para as terras indígenas.

Poucos ou talvez nenhum funcionário do SPI visitou as terras Kadiwéu entre 1930 e 1941. Nesse período, o SPI experimentou uma série de mudanças que o levaram a circular por vários ministérios e afastar-se da reserva ${ }^{8}$. As coisas não foram fáceis para os Kadiwéu durante esses anos. Foram vítimas de uma epidemia de febre amarela que em um mês acabou com a vida de umas quarenta pessoas ${ }^{9}$. Mas, no tocante à questão das suas terras, como já foi dito, os conflitos deixaram de ser tão frequentes quanto no passado mais ou menos recente. Contudo, houve alguns confrontos. O conflito de maior importância durante os anos de afastamento do SPI, envolvendo a posse de terras, foi com Vicente Jaques, proprietário da fazenda Baía das Garças, próxima à aldeia São João, lugar em que, na década de 1920, o SPI estabelecera um grupo de índios Terena para defender e povoar a divisa. Jaques foi acusado como o autor da morte de um índio e de invadir em vários momentos as terras Kadiwéu ${ }^{10}$. A aldeia de São João 
dispersou-se depois do crime e só voltaria a povoar-se com a notícia do regresso do SPI. Nos seguintes meses à instalação da Inspetoria em Campo Grande, em meados de 1941, já sob o nome de 5a Inspetoria Regional (IR5), esta se esforçou, sem sucesso, por esclarecer o assassinato e sustentar uma ação legal contra Jaques ${ }^{11}$. Os índios também continuaram denunciando a invasão. Finalmente, o fazendeiro seria obrigado a desistir da área ocupada ${ }^{12}$.

Conflitos de outra natureza estavam se originando. As ações do Estado para promover a colonização da fronteira e a compra de terras públicas impulsionou, nas décadas de 1940 e 1950, a fragmentação do espaço, a apropriação privada de terras e a formação de fazendas, multiplicando as cercas, as invasões e os confrontos. Em poucos anos, a reserva Kadiwéu ver-se-ia literalmente cercada por fazendas de gado e vizinhos sempre à procura de mais um pouco de terra. A gradativa transformação da estrutura agrária no sul de Mato Grosso ameaçaria seriamente a reserva Kadiwéu e colocaria em dificuldades índios e funcionários do SPI para manter sua integridade.

\section{Expansão da fronteira (1940 - 1950)}

A volta do SPI à reserva Kadiwéu em 1941 correspondeu ao início de uma profunda transformação da fronteira sul-mato-grossense. A remodelação do espaço e as relações da fronteira se enquadravam dentro da política nacionalista desenvolvida por Getúlio Vargas ao longo dos seus governos (1930-1954). Inconsciente ou conscientemente, nacionalista ou oportunista, a política econômica de Vargas durante seu primeiro período foi uma resposta a grave crise internacional que atingiu em cheio o país na década de 1930 (Fonseca, 1989; Furtado, 1977; Bastos, 2011), voltado até então para a produção extensiva e de grande escala de uns quantos gêneros para exportação.

Como instrumento contra a subordinação funcional da produção brasileira ao comércio internacional e em resposta à crise, passou-se a uma forte intervenção do Estado na economia a favor da indústria nacional, adotando medidas para superar a condição primária exportadora do país e o isolamento e especialização produtiva regionais. Dentre as políticas necessárias para o novo projeto de desenvolvimento nacional, em particular a partir do estabelecimento do Estado Novo em 1937, a chamada "Marcha para o Oeste" teve particular relevância. O projeto, criado nesse ano, propunha colonizar as terras da região Centro-Oeste, fornecendo o modelo, e também as aspirações e o imaginário, para 
ocupar regiões de fronteira ${ }^{13}$. Conduzido por uma política econômica nacionalista, a expansão sobre a fronteira foi justificada como um avanço sobre espaços imensos, "vazios" e "desabitados": imaginário sustentado na evocação culturalmente determinada do Sertão (Amado, 1995; Oliveira, 1998, 2008). Este projeto, provido de um forte sentido civilizatório para integrar o interior do Brasil à economia nacional, significaria a transformação das estruturas agrárias predominantes, sustentadas invariavelmente no controle de imensas extensões de terra, e, portanto, também um esforço por diminuir o poder das elites latifundiárias que, como em Mato Grosso, ainda possuíam o controle hegemônico da autoridade política e do poder econômico locais.

Com efeito, por volta de 1940, a estrutura agrária no sul do estado ainda estava dominada pela grande propriedade fundiária. Esta se havia configurado a partir da primeira legislação republicana de terras no estado em 1891. O objetivo dessa legislação foi aplicar os princípios básicos da Lei de Terras de 1850 que, no Mato Grosso, permanecera sem efeitos importantes na fase final do Império. Essa Lei, regulamentada em 1854, reconhecia o direito dos títulos de sesmarias e de posse anteriores, ao mesmo tempo em que estabelecia os mecanismos para mercantilizar as terras públicas, ou devolutas, em face da iminência da abolição do trabalho escravo ${ }^{14}$. Com o advento da Primeira República e a descentralização e considerável autonomia outorgada aos estados, as terras devolutas e o reordenamento jurídico da propriedade ficaram sob o domínio dos poderes estaduais, isto é, sob o controle das elites oligárquicas dominantes, de forte composição militar (cf. Saboya 1995; Silva, 1996; Moreno, 2007; Trinidade, 1995).

O controle que exerceram sobre as instituições destinadas à revalidação de sesmarias e legitimação de posses, compra e o arrendamento de terras devolutas foi determinante na nova configuração fundiária, consolidando antigos e ampliando e criando para si novos domínios. Acrescentou-se à grande propriedade dos grupos tradicionais de militares políticos, as amplas zonas para a descoberta e exploração de produtos vegetais e minerais concessionadas às empresas estrangeiras. Dessa forma, a paisagem fundiária do sul de Mato Grosso, nas primeiras décadas do século XX, estava integrada por latifúndios, como a Companhia Mate Laranjeira (ML) que, entre 1890 e 1943, arrendara do Estado quase 2 milhões de hectares de terras devolutas para a exploração dos ervais do extremo sul do estado. Alves (1984) destaca outras 28 propriedades ligadas a capitais internacionais, estabelecidas no sul de MT entre 1891 e 1929, muitas 
delas localizadas ao longo da estrada de ferro Noroeste do Brasil, como The Miranda Estância Company Limite, a Brazil Land Cattle \& Packing Company, a Brazilian Meat Company, e a Fomento Argentino Sul-americano, vizinha das terras Kadiwéu, e cuja demarcação em começos do século XX se sobrepôs a uma parte significativa da reserva ${ }^{15}$.

A presença desses grandes latifúndios ligados às empresas estrangeiras sempre foi questionada por uma parte da elite mato-grossense. Os argumentos eram de vários tipos, ora políticos, alegando o risco que representavam à soberania nacional ao se localizarem próximas à fronteira; ora econômicos, objetando a racionalidade econômica da concentração fundiária e dos arrendamentos, apontando aos efeitos perniciosos sobre os recursos do estado. Os protestos, resistências e questionamentos, no entanto, não foram suficientes para quebrar o predomínio da grande propriedade agrária. Apenas com o advento do Estado Novo que esse propósito seria atingido, possibilitando, por sua vez, o estabelecimento de colônias agrícolas, a aquisição particular de terras, a formação de fazendas e, com isso, a multiplicação das cercas, invasões e os confrontos, frequentemente violentos, entre índios e fazendeiros. Ao cancelamento do arrendamento a ML, em 1941, por exemplo, seguiu o estabelecimento da Colônia Agrícola Nacional de Dourados (CAND), e arribo de milhares de agricultores pobres, a formação de fazendas voltadas à produção agrícola e pecuária, que passaram literalmente por cima das aldeias Guarani (cf. Brand 1997; Vietta, 1997). Também ocorreu a liberação de milhares de hectares, que foram submetidos à frenética especulação por parte tanto de grupos capitalistas quanto de políticos (Lenharo, 1986b) $)^{16}$.

O ataque do estado de Mato Grosso à Fomento Argentino, em 1943, gerou na região Kadiwéu processos semelhantes aos causados pela Mate Laranjeira no sul, embora menos dramáticos em curto prazo. Nesse ano, a Fazenda Pública do Estado promoveu uma ação legal contra a empresa devido ao atraso no pagamento de impostos ${ }^{17}$. Como resultado, a maior parte dessa propriedade retornou ao poder do estado e uma porção menor, porém dentro do perímetro da reserva Kadiwéu, foi penhorada e arrematada entre diversos concorrentes. A demarcação desse grande latifúndio na bacia do Nalique, em 1914, abarcara, além da fazenda Xatelodo, parcialmente as terras da Reserva Kadiwéu. Ninguém se importara. Talvez porque ninguém tivesse conhecimento ou porque não representava ameaça alguma, pois a empresa nunca se apossou, de fato, das terras indígenas que, nas décadas seguintes, caíram em abandono. 
A sobreposição de títulos de propriedade, no entanto, geraria complicações quando, em 1943, houve a necessidade de avivar as antigas divisas e demarcar os lotes dos sucessores da fazenda. Quase imediatamente, os novos donos das terras da ex-Fomento Argentino se dispuseram a levantar aramados, dando início a conflitos. Assim, Jefferson Bachi, que adquirira 36 mil hectares, pretendia, em dezembro daquele ano, estabelecer uma divisória por linhas secas ao sul do Niutaca, traspassando os limites da reserva ${ }^{18}$. O objetivo de Bachi viu-se paralisado pela ação do SPI, ao menos durante um tempo. Foi só em meados de 1946 que o processo para a aviventação do perímetro da Fomento Argentino, proposto pelos compradores de glebas de terras da antiga concessão dessa fazenda, tomara um curso jurídico mais definido ${ }^{19}$.

Outros problemas se apresentaram paralelamente e indicavam, de igual forma, o início de um novo processo de ocupação do espaço. Particulares e a fazenda Xatelodo, reorganizada sob o nome de Sociedade Agro - Pecuária Xatelodo Ltda., tentaram invadir e explorar as terras Kadiwéu em vários momentos ao longo da década de 1940, com o argumento de terem adquirido terras devolutas ou de terceiros. Em 1942-1943, pessoas provenientes de SP se dispuseram a extrair o babaçu ${ }^{20}$. Em 1946, com o mesmo fim, a fazenda havia instalado maquinaria para seu beneficiamento e aberto roças ${ }^{21}$. Os eventos se traduziram numa série contínua de ações para proteger as divisas: viagens de exploração à cabeceira e curso do Niutaca, protestos, intimações para abandonar as terras invadidas, a suspensão temporária de um funcionário, acusado de complacência com os invasores, ações legais e outras medidas ${ }^{22}$. Apesar de todos esses conflitos, ao final de 1948, o encarregado do PI Alves de Barros informou à IR5 que não havia nenhum "civilizado" ocupando terras dentro das áreas indígenas. 23 No entanto, fora um prelúdio do ataque contundente às terras índias. No decorrer dos seguintes anos, foram aparecendo cada vez mais "aves de arribação", "aventureiros" e "grileiros atrevidos", procurando atravessar as divisas. 24 No começo de 1950, o chefe da IR5, Joaquim Fausto Prado, diria acertadamente:

Como diz o índio Kadiwéu, e com razão, que lutaram quase meio século com seus próprios recursos contra inimigos poderosíssimos e a eles venceram. O Governo acabou reconhecendo os seus direitos. Hoje as terras estão em mãos do Serviço e eles notam que se não tomarem uma enérgica providência povoando as divisas, em breve muito trabalho terá o SPI para garanti-las ${ }^{25}$. 


\section{Fragmentação do espaço e proliferação da fazenda pecuarista (1950-1955)}

Com o fim do Estado Novo, em 1945, e o advento do regime liberal de Dutra (1946-1951), a política fundiária na fronteira não mudou. Os governos estaduais, da mesma forma, deram continuidade ao processo de transferência de terras devolutas às mãos privadas, assim como aos projetos de colonização, impulsionados, novamente, com a volta de Vargas ao poder em $1951^{26}$. O incremento das solicitações de particulares para a compra de terras públicas entre 1940 e 1955 ofereceram um indicador adequado da ocupação do território. Em 1941, houve um sensível aumento, movimento que se duplicaria em apenas um ano $^{27}$. Uma década depois seria uma febre. Entre 1950 e 1954, no governo de Fernando Corrêa da Costa, houve 20.750 pedidos de compra de terras locais em Cuiabá e Campo Grande.

Já em 1951, uma liderança Kadiwéu, João Príncipe, avistara o indício material mais evidente desse processo mais agressivo de ocupação do espaço: denunciou que, no lugar denominado Piúva, existia "um indivíduo mandando fazer aramados o qual os postes já estão todos fincados e furados"28. Mas o ano de 1953 parece ter sido particularmente importante no tocante à tomada de consciência, por parte dos funcionários do SPI e dos próprios índios, das dimensões reais do perigo. Entre junho e julho, o chefe da IR 5 recomendou a todos os encarregados dos PI especial atenção e vigilância sobre a afixação de editais na Coletoria Estadual, referentes a requerimentos de terras que estivessem compreendendo áreas das reservas ${ }^{29}$. De fato, os requerimentos haviam se tornado a principal ameaça para os indígenas. No extremo sul, as terras das aldeias Guarani-Kaiowá, como Sassoró, Porto Lindo, Cerro Perón, Povinho, por exemplo, localizadas em zonas ricas em erva mate, foram requeridas sistematicamente por particulares e sofreram múltiplas tentativas de invasão. Na reserva Kadiwéu, nesse mesmo ano de 1953, as terras requeridas dentro da reserva somavam mais de 30 mil hectares ${ }^{30}$. Nesse momento, o aparecimento de cercas de intrusos construindo posses, assim como visitas dos agentes e a organização de grupos de índios e funcionários para verificar as invasões e outras medidas de fiscalização das divisas, eram as atividades cotidianas.

Fazendas pecuaristas foram estabelecidas ao longo de todas as divisas da reserva, não apenas a partir da compra de terras tidas como devolutas. Ao norte, na divisa com o Niutaca e Nabileque, a maior presença de proprietários 
decorreu principalmente da venda das terras adquiridas pelos sucessores da Fomento Argentino. Ao não conseguirem que alguns deles se apossassem das terras, optaram por vendê-las a terceiros. A invasão denunciada pelo capitão João Príncipe, de fato, havia sido realizada nas terras adquiridas de Sebastião Bachi, um dos beneficiados da arrematação da propriedade da empresa argentina na década anterior. Terras dessa empresa retomadas pelo estado também começaram a ser adquiridas por privados. Vicente Jaques, por exemplo, além de ser dono da fazenda Bahia das Garças, em vários momentos requereu e comprou terras na divisa norte da reserva, provavelmente requeridas ao estado.

Ao sul, na divisa com o córrego Aquidauana, a maior presença de pecuaristas decorreu da fragmentação das antigas propriedades, como Barranco Branco, começada já na década anterior. Novos e velhos vizinhos, proprietários ou arrendatários das novas empresas, foram estabelecendo-se ao logo de toda a margem esquerda do córrego Aquidauana. Ao leste, na Serra da Bodoquena, em 1954, embora uma grande parte da região estivesse sob propriedade de particulares, requerimentos das terras públicas proliferavam. Um sinal de todo esse processo de ocupação do território e formação de fazendas são as frequentes solicitações de indivíduos encaminhadas ao SPI para a colaboração na construção de cercas nas divisas que começaram a aparecer nos primeiros anos de 1950. Havia uma fila de novos proprietários passando pela Inspetoria Regional, solicitando apoio para irem reconhecer e cercar suas novas propriedades. Listados de proprietários confinantes, solicitando arrendamentos de terras, indicam o mesmo processo ${ }^{31}$.

Com um número maior de propriedades nos limites da reserva, incrementaram-se as invasões. Alguns dos fazendeiros tornaram-se velhos conhecidos dos índios. Felisbino Ximenes, por exemplo, foi denunciado varias vezes depois de cercar áreas pertencentes aos indígenas. Outros fazendeiros, tentariam fazer o mesmo, cercando águas, alagadiços e matas, ou procurando construir uma posse dentro das terras, não sem a oposição dos índios ${ }^{32}$. Não houve apenas problemas de limites. Constantes conflitos devidos às entradas de gado alheio tornaram-se também frequentes. Gado transpondo cotidianamente as divisas das terras Kadiwéu era, em parte, uma consequência inevitável da multiplicação das propriedades pecuárias em volta da reserva e, em outra, uma estratégia que se tornaria adequada nos seguintes anos para apropriar-se delas. 


\section{A ocupação da reserva Kadiwéu (1955-1960)}

O reordenamento fundiário no estado, no período de 1950 a 1960, teve como marca a venda indiscriminada de terras e colonização. $\mathrm{O}$ acesso privado à terra, através da aquisição de terras tidas por devolutas ou por meio da compra de lotes que haviam pertencido a antigos latifúndios, possibilitou o crescimento exponencial do número de fazendas pecuárias nas proximidades das divisas da reserva Kadiwéu. As invasões se tornaram comuns, mas foi particularmente a partir de 1957 que aumentaram. Apenas três anos depois, quase metade da sua área se encontrava ocupada por estranhos. Os criadores da região conseguiram entrar nas terras indígenas de duas formas: através de autorizações temporárias outorgadas pelo SPI e pela invasão impune. Independentemente da maneira com que se enfiaram na reserva, a ocupação foi eventualmente oficializada por um sistema de arrendamento instituído pelo SPI em 1960.

Esse apoderamento privado das terras Kadiwéu esteve condicionado por duas circunstâncias associadas ou, pelo menos, congruentes entre si. A primeira foi provocada, presumivelmente, por um evento da natureza: as enchentes dos rios da região obrigaram os fazendeiros a encontrar refúgio para seu gado dentro das terras indígenas; a segunda foi o ataque empreendido pela Assembleia Legislativa do Estado sobre as reservas Kadiwéu em 1957. As duas circunstâncias parecem ter uma estranha relação e sincronia. O primeiro evento precedeu uns meses a tentativa da Assembleia do Estado de reduzir o tamanho da reserva. De fato, desde 1954, era conhecida a pretensão da Assembleia de reduzir a área da reserva pelo menos à metade, objetivo que parece ter sido de conhecimento de todos, inclusive dos funcionários do $\mathrm{SPI}^{33}$. Quiçá foram mesmo as chuvas generosas que obrigaram os criadores a retirarem o gado para áreas mais seguras, dentro das terras Kadiwéu. É possível também que, aproveitando aquele conhecimento, se voltassem em massa sobre as terras índias, antecipando futuras, agora iminentes, ações públicas contra elas. No final, as enchentes eram um evento cíclico: todo ano, períodos alternados de secas e cheias alteravam profundamente a paisagem da região e, em anos anteriores, as autorizações para resguardar o gado dentro da reserva foram quase nulas, mesmo quando esta estava cercada por fazendas pecuárias.

Invasões ocorriam: era uma prática cotidiana entre os vizinhos enviar maliciosamente o gado para os pastos da reserva e, dissimuladamente, deixar que os aproveitassem; inclusive o gado chegava a confundir-se com os pertencentes 
ao SPI ou com os dos índios e, já gordo, era então reclamado pelo proprietário - se antes os índios não o "carneassem”. Mas o argumento das enchentes para se estabelecer dentro da reserva foi pouco recorrente e apenas uma solicitação pode ser registrada nos anos anteriores ${ }^{34}$.

No entanto, em fevereiro de 1957, fazendeiros da região de Coimbra, procurando pontos mais altos e seguros contra as enchentes do Rio Paraguai, solicitaram ao SPI autorização para recolher seu gado dentro das terras Kadiwéu ${ }^{35}$. Nas semanas seguintes, outros pecuaristas, sem autorização, fizeram o mesmo. Atendendo às queixas dos indígenas, um auxiliar foi enviado para percorrer as zonas ocupadas ${ }^{36}$. Contabilizou 14.294 cabeças de gado, pertencentes a 22 fazendeiros que entraram na reserva entre fevereiro e março. Os fazendeiros se comprometeram a pagar as pastagens e a se retirar tão logo fosse possível. Alguns deles saíram nos meses seguintes, mas as solicitações para ingressar os rebanhos se fizeram comuns nas próximas temporadas de chuvas. Entre setembro desse ano e março de 1958, a IR5 autorizou algumas entradas por um prazo de seis meses, a princípio improrrogáveis, notificando aos solicitantes a proibição para explorar qualquer outro recurso do patrimônio indígena existente na reserva. Os funcionários cuidavam de ressaltar que não se tratava de um arrendamento - proibido pelo Ministério de Agricultura - mas apenas um pagamento pela utilização das pastagens durante o tempo em que o gado corresse perigo devido às enchentes. Da mesma forma, o SPI informava que não acolheria pedidos semelhantes no futuro. Porém, as autorizações continuaram, mesmo quando o ataque da Assembleia do Estado às terras indígenas alcançara uma escandalosa notoriedade pública ${ }^{37}$.

Em outubro de 1957, a Assembleia havia apresentado o Projeto de Lei no. 1/077, o qual, através de uma nova redação ao decreto que legalizou, em 1931, a demarcação da reserva no início do século XX, pretendia reduzir a área para menos de um terço do seu tamanho original. O governador do estado vetou-o por considerá-lo inconstitucional ${ }^{38}$. No entanto, a Assembleia pronunciou-se contra essa ação, aprovando o projeto em abril de 1958 e promulgando a lei que pretendia tornar as terras Kadiwéu devolutas, revertendo-as ao domínio de estado. Para então, o número de pessoas que requereram terras da reserva aumentou até alcançar o escandaloso número de 876 , cujas pretensões o SPI teve de combater judicialmente ${ }^{39}$. Sem dúvida, tudo isso apressou muitos fazendeiros a ingressarem na reserva, fosse por meio de autorizações do SPI ou pela 
simples invasão. Em julho de 1958, o SPI foi alertado de intrusos invadindo a área e fazendo posses e mandou organizar uma equipe de índios para percorrer toda a área ${ }^{40}$. O caso da Assembleia continuou até 1961, quando finalmente o Supremo Tribunal Federal deu ganho de causa aos indígenas Kadiwéu e manteve a área com os limites originais ${ }^{41}$.

Não obstante o processo descrito e a crescente onda de invasões, os funcionários do SPI responderam às novas solicitações para resguardar o gado de fazendas vizinhas dentro da reserva sempre da mesma forma: autorizando e regularizando a permanência dos rebanhos, advertindo a seus proprietários de que os contratos seriam apenas temporários, o tempo necessário para evitar a perda dos rebanhos; que não seriam verdadeiros arrendamentos, mas apenas pagamentos pela pastagem, proibindo o uso e a exploração de outros recursos, $\operatorname{etc}^{42}$. O resto foi só efeito da acumulação. As ocupações tornaram-se permanentes e, com isso, a formação de invernadas, a construção de casas, currais e outras benfeitorias. Em algum momento, os funcionários do SPI simplesmente começaram a se preocupar mais com a cobrança do uso das pastagens e o estabelecimento de prazos e multas, instituindo, na prática, algo que havia sido considerado apenas um favor conjuntural propiciado por um evento da natureza.

O processo continuara quase com coerência própria. Para 1960, o chefe da IR5 calculava que 144 mil hectares da reserva (o que correspondia a um terço da área total) estavam ocupados por particulares. Apesar da análise realista do inspetor, que apontava para os requerimentos de terras que continuaram sendo emitidos e, sobretudo, para as autorizações concedidas pelo SPI, como causas do esbulho (omitiu que ele mesmo autorizara medidas semelhantes), o remédio projetado para a situação seria, mais uma vez, o costumeiro; só que, desta vez, os contratos seriam, em toda a expressão da palavra, de arrendamento, legitimando e oficializando, finalmente, a situação construída nos últimos anos.

A regularização de invasores e daqueles que haviam adquirido contratos, formulou-se em um projeto, apresentado em 1960 pela IR5 à diretoria do SPI, para o aluguel de pastagens, considerando a viabilidade do estabelecimento de fazendas de criação de 2 ou 3 mil hectares ${ }^{43}$. A Diretoria do SPI avaliou negativamente a proposta, destacando as consequências potencialmente negativas para a reserva e para os indígenas. No entanto, uns meses depois, iniciaria o processo de medição das terras, sua assinatura aos locatários e o lavramento dos contratos. Embora os contratos indicassem, novamente, sua natureza temporária, e de 
que recorrentemente se apresentaram crises que ameaçaram seu cancelamento definitivo, os convênios continuaram sob novas pressões. Evidentemente, os criadores nunca mais saíram. Em 1963, criaram sua própria organização, chamada “Associação dos Arrendatários das Terras do SPI", confirmando, com isso, de alguma forma, que não tinham qualquer intenção de se retirarem da área ${ }^{44}$.

\section{O papel do SPI na construção do sistema de arrendamentos}

É difícil explicar a conduta contraditória dos funcionários do SPI, sobretudo na segunda metade da década de 1950, quando, alegando o caráter temporário das crescentes ocupações, as transformavam em permanentes. A dificuldade reside em que parece não ter apenas um fator que a explique. Corrupção, ineficácia administrativa, ignorância, todos os argumentos poderosos podem ter sido indissociáveis da prática indigenista, embora sua consideração escape ao escopo do artigo. Mas, certamente, foi uma resposta pouco adequada ao processo de transformação da fronteira, que piorou as condições caóticas que se propunha resolver. O papel do SPI no processo descrito, no entanto, pode ser colocado no âmbito de uma consideração sobre a noção de Estado que ressalte as dimensões processuais da sua dinâmica ou formação.

Lima (1995), utilizando uma linguagem foucaultiana sobre o exercício do poder, que remete a "técnicas”, “esquemas", “dispositivos” disciplinares, "aparelhos de controle", "estatização" etc., argumentou que a finalidade do SPI teria sido implantar, gerir e reproduzir uma forma de poder de Estado, que chamou de poder tutelar. Mas o exercício desta forma de ação do Estado sobre as populações indígenas, com suas técnicas e práticas administrativas, normas e leis, "constituídas e constituintes de um modo de governo sobre o que seria denominado de índio," pode ser pensada, de fato, como menos coerente -- como o mesmo autor indica, embora não seja tão claro a este respeito - e tal como Oliveira (1988) sugeriu ao sublinhar a inconsistência entre "atuação" dos funcionários do SPI e "ideologia indigenista". No exercício de um poder tutelar, o Estado raramente apareceria como uma máquina que manufatura consenso, embora crie mecanismos para isso, manifestando-se frequentemente, na prática, através de ações desunidas e fragmentadas. Isso é o que diversos estudos mostram, contribuindo para desmitificar a coerência estrutural que frequentemente se atribuiu ao Estado nas pesquisas de caráter antropológico e histórico (Abrams, 1988; Corrigan, 1985; Roseberry 1994; Gledhill, 2012). 
Nesse último sentido, um aspecto que chama a atenção na leitura dos principais trabalhos sobre o processo de desapropriação dos territórios indígenas no sul do antigo Mato Grosso, é o predomínio de certa noção instrumentalista e reificada do Estado (cf. Brand, 1997; Vietta, 2007). Contrariamente do que neles se sugere, é difícil ver uma plena correspondência entre os objetivos, interesses e as atuações do SPI, através da IR5, e as de outras instituições com interesses na região, como a Colônia Agrícola Nacional de Dourados (CAND) ou da Delegacia de Terras e Colonização (DTC). Havia negociações, mas o período sob análise esteve marcado, sobretudo, por profundos desentendimentos, acusações e confrontações entre essas instituições ${ }^{45}$.

Esse poder fragmentado do Estado pode ser também observado ao interior do próprio SPI. As instruções ditadas pela alta burocracia, por exemplo, não se replicavam como desígnios que tinham de ser irremediavelmente implementados através de seu corpo de administradores e funcionários. "Manda quem pode, obedece quem precisa”, máxima usada pelo chefe da Inspetoria Deocleciano de Souza entre 1953 e 1954, ao negar-se a substituir um trabalhador por outro nomeado pela Diretoria, parece sintetizar as atitudes dos funcionários com respeito aos seus superiores na estrutura burocrática.

De igual modo, no interior da própria IR 5 as discórdias eram muito comuns (políticas, mas com frequência também de caráter pessoal ou, inclusive, decorrentes de diferenças religiosas), expressão das sérias dificuldades para estabelecer uma administração eficiente, que foi notoriamente inconstante. De 1947 a 1955 houve seis inspetores, quase sem exceção todos acusados em algum momento de fazer uso indevido dos recursos do SPI, inclusive das terras indígenas. Um momento dramático, porém significativo, dessas diferenças foi o assassinato, em 1951, do Inspetor Irineu José dos Santos pelo seu sucessor no cargo, Joaquim Fausto Prado, que se suicidou depois ${ }^{46}$. Em outras palavras, o SPI era um órgão heterogêneo, cortado por perspectivas distintas ou até conflitantes e é nesse contexto de contradições, que cotidianamente contribuíam a reproduzir o poder do Estado, que pode-se entender a posição da IR5 perante os índios e seu papel no processo de desapropriação territorial.

No contexto da progressiva modificação da estrutura agrária e dos sucessivos embates contra as terras indígenas, parece ter havido uma mudança de perspectiva na consideração do papel dos arrendamentos tratados com terceiros por parte dos funcionários do SPI. Além de ser o lugar em que eram aplicadas as 
políticas tutelares, ou, melhor, as consequências disso, os PI, em certo sentido, funcionavam como uma fazenda. O SPI, por meio dos encarregados de Postos, controlava e administrava os seus recursos; decidia, unilateralmente, como se daria o uso de madeiras, cascas de angico, lenha, pedra, não sem a oposição dos indígenas, embora seus protestos geralmente fossem empurrados a um segundo plano. Para isso, era utilizada a mão de obra indígena em troca de um pagamento ou da distribuição de alguns privilégios. Os contratos de arrendamento entre o SPI e terceiros para a utilização dos recursos do patrimônio indígena, porém, sempre foram olhados com desconfiança, pelo menos no âmbito da IR $5^{47}$.

Desde os primeiros anos da década de 1940, quando foi estabelecida a Inspetoria em Campo Grande, e, até meados da década de 1950, as petições para cercar, estabelecer alguma benfeitoria ou qualquer outra ação que significasse a presença contínua de particulares dentro da reserva foram sistematicamente rejeitadas pelas autoridades da diretoria do SPI no Rio de Janeiro. Vários inspetores da IR5, inclusive, ao logo do tempo, tentaram convencer seus superiores de que estabelecer alguns convênios com particulares poderia ser uma boa ideia tanto do ponto de vista econômico, como da proteção das divisas da reserva. Da mesma maneira, as propostas foram rejeitadas, argumentando que não seria um bom negócio e constituiriam uma forma de permitir a expulsão dos índios das suas terras, como havia acontecido em outras Inspetorias e como, de fato, aconteceu na reserva Kadiwéu. Alguns contratos foram estabelecidos, mas foram escassos.

Posteriormente, essa postura hesitante diante dos arrendamentos mudou. Não foi uma mudança unicamente no campo das ideias. Foi uma mudança de perspectiva num contexto que havia mudado dramaticamente. Na década de 1940, os Kadiwéu e o SPI agiram em defesa da reserva ainda num mar verde. Em meados da década de 1950, o cenário era radicalmente distinto e a reserva encontrava-se literalmente cercada por fazendas de criação de gado. As considerações sobre arrendar ou não as terras dos índios se deram nesse contexto. Na medida em que as autorizações outorgadas a fazendeiros para a ocupação temporária se tornaram rotineiras, começaram a ser indispensáveis para o SPI. Primeiro, porque os ingressos obtidos foram avaliados sob a imperiosa necessidade orçamentária em vista do processo legal que o SPI mantinha contra a Assembleia Legislativa do Estado e contra os requerentes das terras Kadiwéu, por um lado. De outro, porque quando a situação parecia incontrolável, os con- 
tratos de arrendamento foram percebidos como uma forma de proteção das divisas e de solucionar os problemas criados nos anos precedentes, decorrentes da ocupação da reserva.

As justificativas do projeto de 1960 para formalizar o sistema de arrendamentos podem ser consideradas como ingênuas, no melhor dos casos. Porém, tentavam superar uma situação de crise. Realmente, apegavam-se aos critérios produtivistas típicos da época, distantes das considerações sobre um território indígena ou sobre os "costumes indígenas", comum do indigenismo anterior. Nesse sentido, essa mudança se combinou com outra, de caráter ideológico, na forma como os problemas dos indígenas eram enquadrados e que, talvez, acompanhasse uma modificação dos quadros da burocracia da IR5 a partir de 1957. Na documentação analisada, é interessante notar que as antigas referências aos "nossos índios", "nossos selvícolas", "os primeiros donos das terras" e outras expressões da convicção tutelar dos funcionários do SPI, rotineiras em anos anteriores, tornam-se menos comuns e substituídas por um interesse mais "técnico".

As ideias que guiavam a proposta de 1960 para solucionar o "problema social" eram essencialmente econômicas: através do arrendamento de 150 mil hectares das terras Kadiwéu, que correspondia à área de fato ocupada, pretendia-se dar um "uso produtivo" para os campos "inaproveitados" (uma expressão carregada de significado, mas sem sentido: as terras de fato já estavam sendo exploradas), e, com isso, trazer "progresso" à região, "aumentar o patrimônio indígena" e o "bem-estar dos índios". Como se as vantagens não pudessem ser melhores, o projeto ainda "pacificaria a região" (referência que reconhece o caráter altamente conflituoso do momento), e "os índios morariam em paz" ${ }^{48}$. Os funcionários, assim, reproduziam as ideias de modernização e desenvolvimentismo adotadas pelos governos federais da época.

Pouco ou nada se cumpriu. A década de 1960 começou com inúmeros problemas causados pela força da presença dos pecuaristas e pelo excesso de trabalho dos funcionários; também pela desordem, a confusão e a incapacidade na administração da IR5: mais invasões, ocupantes sem contrato, vendas irregulares de posses, problemas entre arrendatários, entre estes e os índios, etc. Os problemas eram tantos que, em dezembro de 1962, o chefe da IR5 viu-se obrigado a solicitar a presença de um contingente da Polícia Militar do estado, que devia permanecer por tempo indeterminado na reserva, até a retirada do gado de alguns invasores ${ }^{49}$. 
O sistema de arrendamentos foi, para todos os efeitos práticos, uma usurpação. Foi a maneira através da qual os interesses de particulares, em concordância ou conivência com os públicos conseguiram transformar os campos Kadiwéu em extensões das suas propriedades, alimentando o conflito que predomina até os dias atuais. Foi, enfim, uma das peças importantes na reconfiguração geral da economia política do capitalismo agrário brasileiro na fronteira, que impôs sobre as terras indígenas suas particulares relações produtivas e formas de violência.

Recebido: 19/02/2016

Aprovado: 06/03/2018

José Manuel Flores é doutor em Antropologia Social pelo Centro de Investigación y Estudios Superiores en Antropología Social, México. Realizou pós-doutorado na Universidade Estadual de Campinas e, atualmente, é professor visitante no Instituto de Antropologia da Universidade Federal de Roraima. Contato: floreslopezjm@hotmail.com

\section{Notas}

1. A lei complementar $\mathrm{n}^{\circ} 31$ de 11 de outubro de 1977 dividiu o estado de Mato Grosso, criando o estado de Mato Grosso do Sul, com capital em Campo Grande. A criação do novo estado, porém, efetivou-se só em 1979.

2. O presente artigo foi escrito a partir do fundo documental do SPI, resguardado no Museu do Índio, no Rio de Janeiro. Aqui utilizei tanto a documentação disponível no Museu do índio (também acessível na Internet: http: / /www.museudoindio.gov. br/) como a cópia disponível no Núcleo de Estudos e Pesquisas dos Povos Indígenas (NEPPI), da Universidade Dom Bosco, em Campo Grande-MS. Também foram utilizadas algumas fontes hemerográficas e documentos do Arquivo Público do Estado de Mato Grosso (APMT).

3. Ao morrer, Malheiros já havia transferido a terceiros algumas das suas mais importantes fazendas, como Rio Branco e Barranco Branco. Ainda assim, as proprie- 
dades herança de Malheiros somavam 41,712 hectares. Cf. Correio do Estado, Corumbá, 01/10/1911, p. 3.

4. Do Diretor General, Thomaz Ant. De Mind.a Roiz, ao Presidente da Província, General, Floriano Peixoto, Diretoria Geral dos índios em Cuyaba, 14/06/1885 (Salsa, 2002: 163).

5. Cfr. O Republicano. Órgão do Partido Republicano, Cuyabá, 08/12/1898, p. 1. O francês Emile Rivasseau (1936: 64-68), que percorreu a zona do rio Nabileque entre fins do século XIX e início do XX, dá noticias sobre o conflito entre os Kadiwéu e Malheiros, expressado nas incursões indígenas à fazenda Barranco Branco, assim como o envio de destacamentos militares para pacificar a região.

6. Cf. Mensagem do Presidente do Estado de Matto-Grosso Coronel Antônio Pedro Alves de Barros Á Assembléa Legislativa na Sua sessão extraordinária a 1 de novembro de 1901. Tipografia do Estado, Cuyabá, 1901, p. 6-7.

7. Sobre o contrato entre Malheiros e Bento Xavier: A Reação, 10/06/1903, p. 4. Sobre o conflito entre Bento Xavier e os Kadiwéu: A Reação, 10/07/1902, p. 6-7; 10/09/1902, p. 11-12; 10/11/1902, p. 12.

8. Do Ministério da Agricultura, Indústria e Comércio, ao qual o SPI ficou integrado desde sua criação em 1910, passou em 1930 ao do Trabalho; em 1934 ao de Guerra; e em 1939 voltou a ser organizado no Ministério da Agricultura.

9. Freundt (1947: 24), que esteve entre os Kadiwéu em 1939, fez uma referência a esta epidemia e seu efeito negativo no número de índios, tendência agravada, segundo o autor, pela prática do infanticídio.

10. "Relatório da Inspeção feita ao Posto Indígena Presidente Alves de Barros", março 1941, MI-SPI-IR5-095-192-00-f3.

11. "Pedido de informação sobre assassinato", 18/01/1944, MI-SPI-IR5-6662888-95-f1-2; "Sobre inquérito relativo ao assassinato cometido por Vicente Jaques", 19/01/1944, MI-SPI-IR5-999-323-51-f1; NBNH ao Snr. M.S. Bandeira de Melo, 18/01/1944, SPI-IR5-666-288-95-f1; NBHB a Álvaro Duarte Monteiro, Inspetor Regional do Ministério do Trabalho, 29/01/1944, MI-SPI-IR5-297-259-05-f1.

12. "Instruções sobre a viagem à cabeceira do rio Aquidauana", 06/04/1944, MI-SPI-297-24969-f1-3. Crescencio de Lima Barros, a NBHB, 03/01 / 1944, MI-SPI-IR5-096-335-15-f1; "Verificação de terras invadidas por Vicente Jaques", 14/01 / 1944, MI-SPI-IR5-096-201-80-F1-4; “Instruções e esclarecimentos obre a divisa na cabeceira do Aquidauana”, 21 /02/1944, MI-SPI-IR5-297-249-40-f1-2; “Intimação a Vicente Jaques”, 04/02/1944, MI-SPI-IR5-666-266-31-f1 
13. Sobre o processo de colonização do sul do Mato Grosso: Foweraker, 1982; Lenharo, 1986a; Gressler, 1988.

14. A expressão “devolutas” está ligada à noção de terra devolvida. De maneira específica, a Lei de 1850 definiu as terras devolutas como: a) As que não se acharem aplicadas a algum uso público nacional, provincial, ou municipal: b) As que não se acharem no domínio particular por qualquer titulo legitimo, nem forem havidas por sesmarias e outras concessões do Governo Geral ou Provincial, não incursas em comisso por falta do cumprimento das condições de medição, confirmação e cultura; c) As que não se acharem dadas por sesmarias, ou outras concessões do Governo, que, apesar de incursas em comisso, forem revalidadas por esta Lei; d) As que não se acharem ocupadas por posses, que, apesar de não se fundarem em título legal, forem legitimadas por esta Lei.

15. Sobre a distribuição das grandes propriedades no sul de Mato Grosso no começo do século XX, consultar o mapa apresentado por Rodrigues de Oliveira (2004: 30).

16. A mudança que aqui se descreve pode ser entendida, em termos gerais, com as categorias de frente de expansão e frente pioneira, tal como entendidas por José de Souza Martins (1997), destacando não apenas a diversidade de categorias social, suas diferentes temporalidades assim como os "diferentes modos e tempos de sua participação na Historia” dos povos confrontados. A primeira estaria caraterizada por relações não capitalistas; a segunda, por relações capitalistas, embora reproduzindo formas anacrônicas de exploração. A Marcha para o Oeste, nesse sentido, pode ter começado a quebrar, no caso aqui abordado, essa frente de expansão, como o autor afirma. No entanto, deve se considerar que a situação da parte meridional do MT era distinta à fronteira amazônica, objeto de interesse do autor, devendo-se considerar a longa ocupação permanente e interação e confronto da população "branca", - incluindo às burocracias coloniais, imperiais e republicanas - com os indígenas; bem como a articulação das formas de propriedade e das economias -extrativas e pecuárias- aos mercados internacionais.

17. “As Terras de Nabileque”, s/d, NEPPI, SPI, Microfilme 017, imagens 495-499; "Compradores das glebas de Fomento Argentino violaram o patrimônio dos Índios", 05/07/1946, NEPPI-SPI-IR5-Microfilme 17, imagem 1180; "Verificação de terras invadidas”, 14/01/1944, NEPPI-SPI-IR5-Microfilme 014, imagem 852.

18. Sebastião J. Bachi ao Cel. NBHB, 16/01/1944, MI-SPI-IR5-297-24951-f27-28; "Documentos recebidos sobre as terras dos índios Cadiuéos”, 31/01/1944, MI-SPI-IR5-666-289-13-f1-2.

19. Of. 926, "Solicita autorização para pagamento de despesa à conta da sub consignação orçamentaria de Auxilio aos índios, 16/06/1946, SPI-IR5-999-380-24-f1; 
Of. 74, "Relatório da viagem do RJ ao MT atendendo a defesa judiciária das Terras dos Cadiuéos", 16/07/1946, SPI-IR5-666-296-53-f1-3; Of. 75, "Providências em previsão de vistoria judicial em defesa das terras patrimoniais dos Cadiuéos”, 17/07/1946, SPI-IR5-666-296-54-f1-3. Uma cópia da contestação apresentada por o advogado do SPI pode se encontrar no Processo SPI-332 /47: MI-SPI-IR5-297-256-36-f1-23.

20. Acácio Arruda ao Cel. NBHB, 22/04/1942, SPI-IR5-666303-53-f1; Antônio Rocha a NBHB, Campo Grande, 12/04/1943, SPI-IR5666-276-06-f1-2; "Viagem do Snr. Juvenilio de Melo para o PI Alves de Barros”, 31/03/1943, SPI-IR5-666-28911-f1-2.

21. M/M 274, Do Cel. NBHB ao Chefe da SOA, 25/10/1946, SPI-IR5-666-29661-f1-2; NBHB “Caro Júlio”, 25/10/1946, SPI-IR5-666-29645-f1.

22. Dilermando Silva, Agente VIII, a Carlos Olimpo Paes, chefe da IR5, "Sobre colocar casal nas roças do Sotéro”, 01/10/1947, MI-SPI-IR5-095-188-14-f1; "Sobre colheita de babaçu nas divisas da reserva”, 08/07/1947, MI-SPI-IR5-095-189-42-f1. De Américo Antunes de Siqueira ao Sr. Atenaguara de Campos Amaral, 03/10/1946, SPI-IR5 095-193-75-f1; NBHB ao Sr. Maximiliano Cifuentes Contreras, 22/10/1943, SPI-IR5-666-274-65-f1; “Exploração à cabeceira do córrego Niutaca”, 25/10/1946, SPI-IR5-095-179-59-f1-3; "Relatório de viagem de exploração às cabeceiras e curso do Niutaca, em outubro de 1946”, 08/12/1946, SPI-IR5-297-261-79-f1-4.

23. M/M 29, Agente VIII a Joaquim Fausto Prado, 10/11/1948, NEPPI-SPI-IR5, Microfilme 13, imagem 1790.

24. "Relatório das atividades na IR 5 durante o exercício de 1949", NEPPI-SPI-IR5-Microfilme 025, imagens 829-844.

25. M/M 29, Agente VIII a Joaquim Fausto Prado, 10/11/1948, NEPPI-SPI-IR5-Microfilme 13, imagem 1790.

26. Assim, em 1946, foi criado o Departamento de Terras e Colonização (DTC), em substituição da Diretoria de Terras e Obras Públicas. Com a promulgação da Constituição Estadual nesse ano, foi criada a Comissão de Planejamento da Produção, destinada a orientar a colonização no estado, entre outras funções. Também foi promulgado primeiro Código de Terras do Estado, em 1949. Este código foi modificado em 1951, dilatando os prazos vencidos para a legalização de terras adquiridas do estado, bem como a autorização da colonização por particulares. O caos, a corrupção, expedição de títulos sobrepostos, a especulação de terras, a desorganização da própria DTC, levaram a seu fechamento em 1966 (Moreno, 1999).

27. Relatórios apresentado ao Exmo. Sr. Dr. GetúlioVargas, Presidente da Republica pelo Bel. 
Júlio Strubing Muller, Interventor Federal em Mato Grosso, 1939-1940, 1941 -1942, APMT, Estante 4, n. 72 e 73.

28. Of. 25, "Encarregado do posto Alves de Barros, Dionísio Medina" 4/4/1951, NEPPI-SPI-IR5. Microfilme 013, imagem 660.

29. M/M 319, Francisco Ibiapina Fonseca ao auxiliar Vitorino Nunes Oliveira, 25/06/1953, NEPPI-SPI-IR5-Microfilme 01, imagem 1649; Circular 12, 30/07/1953, NEPPI-SPI-IR5-Microfilme 020, imagem 881.

30. Telegrama 236, "Noticias alarmantes referentes a existência de requerimentos”, 03/08/1953, NEPPI-SPI-IR5-Microfilme 017, imagem 1481; M/M 463, Deocleciano de Sousa Nenê a Enoch Alvarenga Soares, 14/08/1953, NEPPI-SPI-IR5-Microfilme 011, Imagem 2276; M/M 461, Deocleciano de Souza Nenê a Edgar E. S. Silva, 14/08/1953, NEPPI-SPI-IR5-Microfilme 13, imagem 589; "Relatório da viagem aos postos da Reserva Cadiuéos”, 30/09/1953, NEPPI-SPI-IR5-Microfilme 017, imagem 420-422.

31. Ao Sr. Agente Vitorino Oliveira, PI Alves de Barros”, 12/11/1954, MI-SPI-IR5-095-182-42-f1; M/M 546, "PI. Alves de Barros”, 24/08/1955, MI-SPI-IR5-095182-94-f1.

32. Of. 269, "Protesto sobre invasão de terras", MI-SPI-IR5-297-255-63-f1.

33. Of. 32, Deocleciano de Souza Nenê ao Diretor do SPI, 22/02/1954, NEPPI-SPI-IR5-Microfilme 17, imagem 957; Of. 262, Deocleciano de Souza Nenê ao Diretor do SPI, 15/10/1953, NEPPI-SPI-IR5-Microfilme 17, imagens 959-960.

34. Cf. Acácio Arruda, encarregado do PI Alves de Barros, 12/04, sem ano, MI-SPI-IR5-095-188-03-f1.

35. “Ao Ilmo Sr. Inspetor do SPI”, 17/02/1957, MI-SPI-IR5-297-259-01-f1.

36. Ordem de Serviço n. 2. Erico Sampaio, chefe da IR5, 03/03/1957, MI-SPI-IR5-297-256-18-f1; M/M 988, Erico Sampaio ao Encarregado do PI Nalique, 02 / 1957, MI-SPI-IR5-094-164-18-F1; "Relatório da viagem aos campos dos índios Cadiuéos”, 18/04/1957, MI-SPI-IR5, 999-337-28-f1-44.

37. Cf. Erico Sampaio ao encarregado do Posto São João, 7/03/1958, MI-SPI-IR5096-200-13-f1; comunicações do chefe substituto da IR5, José Mongenot, ao encarregado do Posto São João: 29/07/1958, MI-SPI-IR5-096-200-14-f1; 28/07/1958, MI-SPI-IR5-096-200-15-f1; 29/07/1958, MI-SPI-IR5-096-200-14-f1; 7/08/1958, MI-SPI-IR5- 096-200-19-f1-2.

38. "Assembleia Legislativa do Estado. Da nova redação aos dispositivos do Decreto lei n. 34 de 9 de abril de 1931 e outras providencias”, 16/10/1957, NEPPI-SPI-IR- 
5-Microfilme 018, imagem 497; Mensagem do Governador do Estado à Assembleia Legislativa, 18/11/1957, NEPPI-SPI-IR5-Microfilme 018, imagens 498-499

39. "Relação de pessoas que requereram terras dentro dos limites da reserva dos índios Cadiuéos”, 1958, NEPPI-SPI-IR5-Microfilme 17, imagens 2103 - 2130.

40. M/M Ao Sr. Encarregado São João, 09/06/1958, MI-SPI-IR5-096-200-07-f1.

41. "Mandato de segurança contra o ato do presidente da Assembleia Legislativa do Estado”, 5/06/1958, MI-SPI-IR5, 297-299-51-f1-6.

42. "Encarregado do Posto São Joao", 07/08/1958, MI-SPI-IR5-096-200-1919-f1-2.

43. "Memorial apresentado pela Chefia da IR5 ao Exmo. Sr. General Diretor relativo ao aluguel de pastagens nas terras reservadas aos índios Kadiwéu”, dezembro 1960, MI-SPI-IR5-297-249-51 f7-12.

44. Of. 42, "Associação de Arrendatários das Terras do SPI ao chefe IR5", 26/02/1964, NEPPI-SPI-IR5-Microfilme 021, imagem 996.

45. O leitor interessado nesses conflitos pode consultar: Of. 157, Iridiano Amarinho de Oliveira ao Diretor do SPI, 11/12/1952, NEPPI-SPI-Microfilme 029, imagens 2086-2087; Of. 95, Iridiano Amarinho de Oliveira ao Sr. Elpidio Moreira Prado, Administrador da CAND, 29/09/1952, NEPPI- IR5-Microfilme 021, imagens 1023-1025; Of. 263, Administrador da Colônia Agrícola Nacional de Dourados ao Inspetor do SPI, 03/08/1950, NEPPI-SPI-IR5-Microfilme 029, imagens 2094-2095; Of. 76, Chefe da IR5 ao Diretor da Delegacia Especial de Terras e Colonização, 06/04/1953, NEPPI-SPI-Microfilme 018, imagem 701; Of. 112, Chefe da IR5 ao Diretor da Delegacia Especial de Terras e Colonização, 07/10/1952, NEPPI-SPI-IR5-Microfilme 19, imagens 1072-1044.

46. As causas do crime e do suicídio provavelmente ficarão soterradas no passado, pois a documentação relativa a esse ano é escassa. Porém, é quase certo que o desvio de recursos ou fraude administrativo estiveram entre os motivos: "Exmo. St. José Maria da Gama Malcher, Diretor do SPI", s/d, NEPPI-SPI-IR5-Microfilme 019, imagens 2202-2203.

47. “Ao Sr. Inspetor do Serviço de Proteção aos Indígenas”, 13/02/1957, NEPPI-SPI-IR5-Microfilme 017, imagem 1939.

48. Cf. Nota de rodapé n. 43.

49. Of. 187, José Fernando Cruz ao Sr. Delegado Especial da Zona Sul em Campo Grande, 12/12/1962, NEPPI-SPI-IR5-Microfilme 017, imagem 950. 


\section{Referências Bibliográficas}

ABRAMS, Philip. 1988. "Notes on the Difficulty of Studying the State", Journal of Historical Sociology, 1 (1): 58-89.

ALVES, Gilberto Luiz. 1984. Mato Grosso e a História: 1870-1929 (Ensaio sobre a transição da casa comercial para a hegemonia do capital financeiro). São Paulo: Ed. da AGB, (Boletim paulista de Geografia), n. 61.

AMADO, Janaína. 1995. “Região, sertão, nação”. Estudos Históricos, vol.8, n 15 : $145-52$.

ARRUDA, Larissa Rodrigues Vacari de. 2015. Disputas oligárquicas: as práticas políticas das elites mato-grossenses (1892-1906). São Carlos: EdUFSCar.

AZANHA, Gilberto. 2005. "As terras indígenas Terena no Mato Grosso do Sul”. Revista de Estudos e Pesquisas, 2 (1): 61-111.

BASTOS, P. 2011. "Qual era o projeto econômico varguista?". Revista Estudos Econômicos, 41(2): 345 - 382.

BORGES, Fernando Tadeu de Miranda. 2001. Do extrativismo à pecuária: algumas observações sobre a história econômica de Mato Grosso. 1870 a 1930. São Paulo: Scortecci.

BRAND, Antônio. 1997. O impacto da perda da terra sobre a tradição Kaiowá / Guarani: os difíceis caminhos da Palavra. Tese em História, PUC/RS.

CAVALCANTE, Thiago Leandro V. 2013. Colonialismo e Território e Territorialidade: a luta pela terra dos Guarani e Kaiowá em Mato Grosso do Sul. Tese de Doutorado, Faculdade de Ciências e Letras de Assis, UNESP.

CORRÊA, Valmir Batista e Lúcia Salsa CORRÊA. 2010. "Charqueadas: una alternativa na economia pecuária do sul de Mato Grosso (1880-1930/40)”. Revista de História, 2 (3): 11-18.

CORRIGAN, Philip; SAYER, Derek. 1985. The Great Arch: English State Formation as Cultural Revolution. Oxford: Basil Blakewell.

CRESPE, Aline Castilho. 2015. Mobilidade e Temporalidade entre os Kaiowá no Mato Grosso do Sul. Tese de Doutorado em Historia, UFGD.

EREMITES DE OLIVEIRA, J; PEREIRA, Levi M. 2013. Nande ru Marangatu:Laudo antropológico e histórico sobre uma terra Kaiowá na fronteira do Brasil com o Paraguai, município de Antônio Joao, MS. Dourados: UFGD.

. 2003. Perícia antropológica, histórica e arqueológica da Terra Indígena Terena de Buriti. Justiça Federal - Campo Grande, MS.

. 2007. "Duas no pé e uma na bunda": da participação terena na guerra entre o Paraguai e a Tríplice Aliança à luta pela ampliação dos limites da Terra Indígena 
Buriti”. História em Reflexão, v. 2:1-20.

FANAIA, João E. A. 2010. Elites e práticas políticas em Mato Grosso na Primeira República (1889-1930). Cuiabá: Ed. UFMT.

FONSECA, Pedro Cezar Dutra. 1989. Vargas: o capitalismo em construção. São Paulo: Ed. Brasiliense.

FOWERAKER, Joe. 1982. A luta pela terra: a economia política da fronteira pioneira no Brasil. Tradução de Maria Júlia Goldwassar. Rio de Janeiro: Zahar.

FURTADO, Celso. 1977. Formação Econômica do Brasil. 15 ed. São Paulo: Brasiliense.

FREUNDT, Erich. 1947. Índios de Mato Grosso. São Paulo: Edições Melhoramento.

GILMARA, Yoshihara Franco. 2014. A ordem republicana em Mato Grosso: disputas de poder e rotinização das práticas políticas, 1889-1917. Tese de Doutorado, Universidade Estadual Paulista "Júlio de mesquita Filho", Faculdade de Ciências humanas e Sociais (FCHS)-Franca.

GLEDHILL, J. (org.); SHELL P. A. (org.). 2012. New Approaches to Resistance in Brazil and México. Durham: Duke University Press.

GRESSLER, Lori Alice; SWENSSON, Lauro J. 1988. Aspectos históricos do povoamento e da colonização do estado de Mato Grosso do Sul. Dourados: Dag.

LENHARO, Alcir. 1986a. Colonização e Trabalho no Brasil: Amazônia, Nordeste e Centro-Oeste. Campinas: Editora da Unicamp. 1986b. "A terra para quem nela não trabalha. A especulação com a terra no oeste brasileiro nos anos 50”. Revista Brasileira de História, 6 (12):47-64.

LIMA, Antônio C. 1995. Um grande cerco de paz: poder tutelar, indianidade e formação de Estado no Brasil. Petrópolis: Vozes.

LUTTI, A. C. C. 2009. Acampamentos indígenas e ocupações: novas modalidades de organização e territorialização entre os Guarani e Kaiowá no município de Dourados - MS: (19902009). Dissertação de Mestrado em História, UFGD.

MARTINS Guillen, Isabel C. 1999. "A luta pela terra nos sertões de Mato Grosso”. Estudos Sociedade e Agricultura, 12: 148-168.

MARTINS, José de Souza. 1997. Fronteira: a degradação do outro nos confins do humano. São Paulo: Hucitec.

MORENO, Gislaene. 2007. Terra e Poder em Mato Grosso. Politica e mecanismos de burla (1892-1992). Cuiabá: Entrelinhas: EDUFMT.

MORENO, Gislaene. 1999. “O Processo Histórico de acesso à terra em Mato Grosso”. Geosul, 14 (27): 67-90.

MÜLLER, Aline Mari. 2011. Índios Kadiwéu e posseiros na Serra do Bodoquena: repre- 
sentações na mídia impressa acerca de um conflito. Dourados: Dissertação (Mestrado em História), Universidade Federal da Grande Dourados.

MURA, Fabio. 2004. "O tekoha como categoria histórica: elaborações culturais e estratégias Kaiowá na construção do território”. Fronteiras, 8 (15): 109-143.

. 2006. À procura do "bom viver”: território, tradição de conhecimento e ecologia doméstica entre os Kaiowá. Tese de doutorado em Antropología Social, UFRJ.

OBERG, Kalervo. 1949. The Terena and the Caduveu of Southern Mato Grosso, Brazil. Smithsonian Institution, Institute of Social Anthropology, Publication No. 9.

OLIVEIRA, João Pacheco de. 1988. O nosso governo: os Ticuna e o regime tutelar. São. Paulo, Marco Zero, Brasília: MCT/CNPq.

OLIVEIRA, Lúcia L. 1998. "A Conquista do espaço: sertão e fronteira no pensamento Brasileiro”. Revista História, Ciências, Saúde, 5 (suplemento):195-215. . 2008. "Estado Novo e a conquista de espaços territoriais e simbólicos". Revista Política e Sociedade, 7 (12): 13-21.

PACHECO, R. A. S. 2004. Mobilização Guarani Kaiowá e Ñandeva e a (re)construção de territórios (1978-2003): novas perspectivas para o Direito Indígena. Dissertação de Mestrado em História, UFGD.

PEREIRA, Levi M. 2007. "Mobilidade de processo e processo de territorialização entre os Guaranis atuais”. História em Reflexão, 1(1):1-33. . 2005. Relatório de identificação da Terra Indígena Taquara. Município de Juti, Mato Grosso do Sul. Documentação FUNAI, Brasília (mimeo). . 2002. Relatório de identificação da Terra Indígena Guyra Roká. Município de Caarapó, Mato Grosso do Sul. Documentação FUNAI, Brasília (mimeo).

RIVASSEAU, Emilio. A vida dos índios Guaycurús. Quinze dias nas suas aldeias. São Paulo: Companhia Editora Nacional, 1936. (Coleção Brasiliana, vol. 60).

RODRIGUES DE OLIVEIRA, José Roberto. 2004. Terras Devolutas de áreas ervateiras do sul de Mato Grosso: A difícil construção da pequena propriedade, 1916-1948. Dissertação, Programa de Pós-graduação em História, Universidade Federal de Mato Grosso do Sul.

ROSEBERRY, William. 1994. "Hegemony and the Language of Contention". In JOSEPH, Gilbert K. (org.); NUGENT, Daniel (org.). Everyday of State Formation. Revolution and Negotiation of Rule in Modern México. Durham: Duke University Press, p. 355-325.

SABOYA, Vilma Eliza Trinidade de. 1995. "A Lei de Terras (1859) e a Política Imperial: seus reflexos na província de Mato Grosso", Revista Brasileira de História, 
15(30): 115-136.

SALSA CORRÊA, Lúcia. 2002. "A fronteira indígena no sul de Mato Grosso, século XIX. Fontes comentadas". Tellus, 2 (2): 155-169.

SILVA, A. B. da. 2007. Mais além da "aldeia": território e redes sociais entre os Guarani de Mato Grosso do Sul. Tese de doutorado em Antropologia Social, URFJ.

SILVA, Lígia Osório. 1996. Terras devolutas e latifúndios. Efeitos da lei de terras de 1850. São Paulo: Editora da UNICAMP.

SILVA, Giovani José da. 2004. A reserva Indígena Kadiwéu, 1899-1984: memoria, identidade e história. Dourados: UFGD.

TRINIDADE, V. E. 1995. “A Lei de Terras (1850) e a Política Imperial. Sus reflexos na Província de Mato Grosso”. Revista Brasileira de História, 15 (30): 115-136.

TRUBILIANO, Carlos Alexandre B. 2014. "No rastro da boiada: pecuária e ocupação do sul de Mato Grosso (1870-1920)”. Revista Crítica Histórica, n. 9: 174-196.

VIETTA, Katya. 2007. História sobre terras e xamãs Kaiowá: territorialidade e organização social na perspectiva dos Kaiowá de Panambizinho (Dourados - MS) após 170 anos de exploração e povoamento não indígena na faixa de fronteira entre o Brasil e Paraguai. São Paulo: Tese de Doutorado em Antropologia Social, Faculdade de Filosofia Letras e Ciências Humanas da Universidade de São Paulo, USP.

WILCOX, Robert W. 2017. Cattle in the Backlands. Mato Grosso and the Evolution of Ranching in the Brazilian Tropics. Austin: University of Texas Press. 
Resumo: Este artigo aborda o processo de desapropriação das terras indígenas no sul do estado de Mato Grosso, em meados do século XX, focando no caso particular da reserva Kadiwéu, criada em 1900, e localizada no município de Porto Murtinho, no atual estado do Mato Grosso do Sul. A problemática é colocada no contexto do avanço da fronteira e da transformação na estrutura agrária mato-grossense entre os anos de 1940 a 1960, período crucial na titulação privada de terras e, consequentemente, da apropriação de terras indígenas no sul do estado. No final deste período, uma parte significativa da reserva havia passado ao controle de pecuaristas da região, através de um sistema de arrendamentos estabelecido pelo Serviço de Proteção aos Índios (SPI), peça chave no processo de integração das terras à esfera produtiva em formação em claro detrimento da população Kadiwéu no estado.

Palavras chave: Reserva Kadiwéu. Expansão da fronteira. Desapropriação de terras indígenas. SPI.
Abstract: This article deals with the process of expropriation of indigenous lands in the south of Mato Grosso in the mid-20th century, focusing on the particular case of the Kadiwéu reserve, created in 1900 , and located in the municipality of Porto Murtinho, in the present Mato Grosso do Sul. The problem is placed in the context of the Mato Grosso frontier expansion and its agrarian structure transformation from 1940 to 1960 , a crucial period in the private titling of land and, consequently, the appropriation of indigenous lands in the south of the state. At the end of this period, a significant part of the reserve had been transferred to cattle ranchers in the region due to a system of settling established by the Indian Protection Service (SPI), a key factor in the process of integrating land into the productive sphere in formation.

Key Words: Kadiweu reserve. Frontier expansion. Land expropriation. SPI. 